insolvent or there is a gradual decrease in profitability of their activities. Therefore, each business entity must actively seek all possible ways to increase effectiveness of their activities taking into account effects of crises.

\title{
References:
}

1. Bezruchenko I.V. Profitability of the enterprise as the main indicator of efficiency of its activity. Available at: file:///C:/Users/User/Downloads/280-740-1-PB\%20(6).pdf (accessed 12.06.2021)

2. Profitability. The essence and indicators. Available at: https://www.finalon.com/ metodyka-rozrakhunku/229-rentabelnist (accessed 19.06.2021)

3. The essence and methods of calculating profitability. Available at: https://finpdotme.wordpress.com (accessed 22.03.2021)

4. Nepochatenko O.O., Melnichuk N.Yu. (2013). Finance of enterprises. Kyiv: Center for Educational Literature

5. Kurochkina O.K. Profitability of the enterprise as the main indicator of efficiency of its activity. Available at: file:///C:/Users/User/Downloads/6877 (accessed 28.03.2021).

6. Berdar M.M. (2010). Finance of enterprises. Kyiv: Center for Educational Literature.

7. Sviridova S.S., Pozhar O.O., (2014). Assessment of factors influencing the profitability of the enterprise. A young scientist, 11 (14), 93-96.

8. Profitability of the enterprise: theoretical bases. Available at: https://ru.osvita.ua/ vnz/reports/econom_pidpr/19538/ (accessed 10.07.2021)

9. Andriychuk V.G. (2002). Economics of agricultural enterprises: a textbook. Kyiv: KNEU.

10. Dolgorukov Yu.A. (2006). Management of working capital efficiency in industry. Finance of Ukraine, 11, $103-105$.

11. Epifanova I.Y., Syoma O.O. (2012). Formation and use of profit in the system of sustainable development of enterprises. Economic space, 67. Dnipropetrovsk: PDABA. 248-254.

Дата подання публікації 10.08.2021p.

\section{UDC 331.101.31}

Anna Zaporozhets $\mathrm{PhD}$ in Economics (Candidate of Economic Sciences), Associate Professor of the Department of Management and Public Administration, https://orcid.org/0000-0001-6345-9474

\section{APPROACHES AND METHODS OF DEVELOPMENT, ADOPTION AND IMPLEMENTATION OF MANAGEMENT DECISIONS}

\author{
Kharkiv National University of Municipal Economy named after ОНМ. Бекетова
}

Any purposeful human activity is always associated with decision-making, and this process is a structural element, the most important attribute of activity. In all spheres of society, at all levels of management, the managerial decision is the main activity of the leader. The process of development, adoption, organization of implementation and implementation of such a decision reflects the content and essence of management and is considered in science as a specialized activity designed to streamline relations between people and subjects of socio-economic relations. This is a mechanism for empowering management entities to direct the process of joint activities of people to solve common socio-economic problems.

The article analyzes the general approaches and methods of development, adoption and implementation of management decisions. Development and decision-making is a certain sequence of actions (operations), which ensures decision-making. Development and decision-making - a number of different, but fairly typical procedures, which are separate stages in the management process, which allows you to build a general scheme of the management decision-making process.

The study of approaches and methods of development and implementation of management decisions allowed us to determine that the development and adoption of management decisions is a certain sequence of actions (operations), which ensures decision-making. Development and decision-making - a number of different, but fairly typical procedures, which are separate stages in the management process, which allows you to build a general scheme of the management decision-making process. There are two main approaches to making management decisions: centralized and decentralized. Traditional, economic-mathematical, systematized and system-target methods should be used in the development and adoption of management decisions. problem

Keywords: management decision, manager, aspects of acceptance, implementation, responsibility, 


\title{
ПІДХОДИ ТА МЕТОДИ РОЗРОБКИ, ПРИЙНЯТТЯ ТА РЕАЛІЗАЦЇ̈ УПРАВЛІНСЬКИХ РІШЕНЬ
}

\author{
Харківський національний університет міського господарства ім. О.М. Бекетова
}

Будь-яка цілеспрямована діяльність людини завжди пов'язана з прийняттям рішень, а процес цей є структурним елементом, найважливішим атрибутом діяльності. У всіх сферах суспільства, на всіх рівнях управління управлінське рішення являє собою основний вид діяльності керівника. Процес вироблення, прийняття, організації виконання та реалізації такого рішення відображає зміст і сутність управління і розглядається в науці як спеціалізована діяльність, покликана впорядкувати відносини між людьми і суб'єктами соціально-економічних відносин. Це механізм наділення суб'єктів управління повноваженнями направляти процес спільної діяльності людей на рішення загальних соціально-економічних проблем.

В статті проаналізовані загальні підходи та методи розробки, прийняття та реалізації управлінських рішень. Розробка та прийняття управлінських рішень це певна послідовність дій (операцій), завдяки яким забезпечується прийняття рішень. Розробка та прийняття рішень - це цілий ряд різноманітних, але досить типових процедур, що представляють собою окремі етапи в процесі управлінської діяльності, що дозволяє побудувати загальну схему процесу прийняття управлінських рішень.

Проведене дослідження підходів та методів розробки та реалізації управлінських рішень дозволило визначити, що розробка та прийняття управлінських рішень це певна послідовність дій (операцій), завдяки яким забезпечується прийняття рішень. Розробка та прийняття рішень - це цілий ряд різноманітних, але досить типових процедур, що представляють собою окремі етапи в процесі управлінської діяльності, що дозволяє побудувати загальну схему процесу прийняття управлінських рішень. До вироблення управлінських рішень існує два основних підходи: централізований i децентралізований. При розробці та прийнятті управлінських рішень слід би застосовувати традиційні, економіко-математичні, систематизовані та системно-цільові методи. проблема

Ключові слова: управлінське рішення, керівник, аспекти прийняття, реалізація, відповідальність,

Statement of the problem in general and its connection with important scientific and practical tasks. In modern conditions, the achievement of specific results of management is impossible without understanding the nature of management decisions, ways to develop, adopt and implement them. The effective work of the subjects of economic relations is directly related to the process of development, adoption and implementation by management and managers of management decisions. The role of management decisions has grown significantly in terms of scientific and technological progress, which on the one hand - significantly expands the capabilities of managers at different levels and increases the speed of management decisions, and on the other - improves the scientific basis of management decisions, its optimization and efficiency. Improving the efficiency of development and implementation of management decisions by improving its technology - a very difficult task,

Analysis of recent studies that have begun to address the problem. The study of issues related to solving problems related to improving the technology of management decisionmaking in the enterprise is given considerable attention by foreign and domestic scientists, such as: G. Simon, T. Saati, D. Derlow, M. Bolyukh, Z. Burchevsky., I. Gevko, M. Gorbatok, N. Ivanchenko, G. Atamanchuk, Y. Korolev, V. Korotnev, N. Mala, I. Pronik, M. Orliv, V. Stadnyk, M. Yokhna, V. Kolpakov, E Smirnov, A. Shegda, R. Fatkhutdinov, V. Yukaeva, V. Yatsyuruk and many other researchers. However, many questions remain unnoticed by scientists. Thus, the issue of improving the technology of making and implementing management decisions remains an understudied problem of modern management and requires a more in-depth analysis of areas and ways to improve them.

Objectives of the article. The purpose of the study is research of theoretical aspects of making and implementing management decisions at the enterprise.

Presentation of the main material of the study with a full justification of the obtained scientific results. Development and decision-making is a certain sequence of actions (operations), which ensures decision-making. Development and decision-making - a number of different, but fairly typical procedures, which are separate stages in the management process, which allows you to build a general scheme of the management decision-making process. There 
are two main approaches to making management decisions: centralized and decentralized.

With a centralized approach, most decisions are made by the top management of the organization. The decentralized approach encourages managers to transfer responsibility for decision-making to a lower management level. This approach frees senior executives from small day-to-day operations.

One of the obvious advantages of the decentralized approach is the imposition of special responsibility in decision-making on local leaders, emphasizing the importance of their powers. The degree of decentralization in the decision-making process depends on the preferences of individual leaders, organizational structure and other factors. The preference given to an approach depends on many factors: the competence of the leader, the level of qualification of the team, the nature of the tasks, resources, etc.

Each of these approaches can be implemented in individual or group forms.

The individual form of decision-making involves the participation in this process only the head. This form is often better when the time and money to make a decision is small or group decision making is not possible purely physically.

In group form, the leader and several (one or more employees) work together on one problem (boards, meetings, debates, participation systems, etc.). An important advantage of this form of decision-making is the ability of the decision-maker to gather more information to develop alternative solutions and thus prevent gross errors and abuses and increase the validity of the choice. The use of the group form is based on two assumptions:

- the group makes decisions easier than one person;

- group decision is easier to implement.

However, the group decision-making reduces the efficiency of management and "blurs" the responsibility for its results.

The success of the participation system depends on the nature of the problem. One of the simplest forms of the participation system is the "Suggestion Box", in which employees drop written proposals (signed or not) on a specific issue, which the manager later reads and considers.

Significantly increase the efficiency of decisions, regardless of approaches to decisionmaking and the use of various forms of implementation of this process is possible by carrying out the necessary actions and operations in a strict logical sequence.

The decision-making process should begin with identifying the problem, which means the deviation of the situation from the desired state, ie identifying the discrepancy between the real, observed state of the controlled system and its desired state.

The signal for the leader to start looking for ways, ways of action that allow to fully or partially solve the problem, is his feeling, which arose as a result of observing the relevant process.

Recognition of the problem becomes a necessary condition for its solution. After all, if there is no problem, then a decision is not required.

Recognition or non-recognition of the problem largely depends on the direct perception of the situation by the manager and has the following possible options:

- the problem is "lowered from above" and the leader can only admit it;

- it is necessary to make a quick decision due to lack of time to think and acknowledge the problem;

- the problem has appeared before, most likely, the decision which was made earlier will be chosen;

- due to the rapid development of emotional passions there is a feverish search for a similar problem in the past (the so-called abbreviation search);

- the manager has previously faced similar problems, but the problem currently considered has significant features;

- the manager knows that the leading decision-making is specific deterministic factors, but he is unable to adequately formulate the goal of a single objective function and is forced to 
resort to several evaluation criteria (multicriteria task);

- the head is not the only subject of decision-making, there are several other subjects, whose opinion cannot be ignored due to the legal, contractual or conflict relations formed between them (behavioral uncertainty);

- lack of experience in solving the problem;

- the problem is so complex that the manager can not deal with it.

Management experts rightly say that if you identify the problem in a timely and correct manner, then half solve it [Error! Reference source not found.]. Therefore, an integral part of this process is to identify problems, penetrate into their essence and correct interpretation. This will help the diagnosis, designed to establish the nature of the problem, its content, the degree of persistence, the relationship with other problems, the types and extent of hazards arising from the problem. Diagnosis is based on the study, analysis, study of the symptoms of the problem, ie the observed signs that indicate its presence.

Interpretation of a problem after its detection is the definition of the nature of the identified problem as an opportunity, as a crisis or as a routine problem. Accordingly, different types of solutions are required in each case.

After defining and formulating the problem, it is necessary to establish the goals and criteria for the solution. Goals set the direction in the search for alternatives. It also includes issues related to decision-making methods and the reduction of emotional tension in the early stages of the decision-making process.

Given that decisions are judged by the results obtained, consideration of the latter is a significant part of the whole process. The results are evaluated using certain criteria, which are the basis of the actual choice. Therefore, before developing alternative solutions, you need to have a clear idea of what the leader needs to achieve.

The most typical criteria for decision making are the following: speed, minimum risk, etc.

Then the manager ranks the criteria according to the principle of their importance to the organization. Criteria have different meanings. For example, some of them are mandatory restrictions, while others simply capture the desired characteristics that serve as guidelines when evaluating solutions. To make a fairly effective decision, the criteria should be divided into strict constraints and desired characteristics. Then it is important to rank the criteria classified as desirable, to find a compromise between mutually exclusive criteria. Many possible solutions need to be ruled out, as the organization often lacks the resources to implement appropriate solutions. In addition, the cause of the problem may be factors outside the organization that the manager is unable to change, such as laws, government regulations, and so on. Such restrictions narrow decision-making opportunities. These are strict criteria, they are not revised in the process of further development of the solution.

Taking into account the time factor sometimes forces managers to rely on thought or even intuition, whereas under normal circumstances they would prefer rational analysis. A necessary prerequisite for making the right decision is the optimal amount and quality of processed information. On the one hand, the more information a manager has, the more likely he is to make the right decision. However, increasing the amount of information does not always improve the quality of the solution. Managers often suffer from an excess of irrelevant information.

In the absence of information, there is a risk of making an insufficiently reasoned decision. In the absence of the necessary information, the basis of choice can only be a known intended course of action, and the determining factor of choice - the subjective opinion of the head, including based on intuition.

Developing alternative solutions allows you to find a better solution, given all the limitations. For standard solutions, managers can use previous own or borrowed experience, existing standards, rules, etc. More complex types of solutions, especially innovative, cause some difficulties at this stage. In this case, it is necessary to apply a creative approach, which 
is the use of various optimal methods: "brainstorming", "Delphi", group analysis of the situation and so on.

The process of developing alternative solutions is based on the collection of relevant information on the problem and its analysis. Information can be obtained from many sources, such as independent experts, management staff, publications, own documents, etc.

In cases where none of the known alternatives seems appropriate, you can use the method of optimization of criteria, which is used in situations where traditional methods of developing alternatives do not give or can not even give acceptable results. The essence of the method is to combine the best features, characteristics of known alternatives.

After compiling a complete list of desired end results, the so-called design criteria, each criterion is taken in turn, and "ideal" solutions are constructed to achieve the final desired result in the absence of any evaluation of alternatives.

This process is repeated for each criterion until the optimal ideas are identified. It is at this stage that criteria-based decision-making is needed and creative innovative ideas are needed.

After compiling a list of optimal ideas for each of the criteria separately, their evaluation, based on them, a combined, comprehensive alternative is constructed.

Then the optimal ideas are compared for their mutual support. They can be natural combinations that mutually reinforce and complement each other. Such combinations should be used as a basis for the future final alternative.

Evaluation and comparison of alternatives is a stage at which both limitations and real opportunities, forces and means at the disposal of the subject of management for the decision of a task are considered.

Comprehensive and reasoned accounting of all the pros and cons will focus on one of them, and the best is not at all, but only in relation to a particular management situation.

The choice of solution should be based on one or more criteria. In all cases, the main criterion should be the achievement of socially significant results, the greatest compliance with the objectives of the organization.

Restriction of individual interests, inevitable in resolving certain issues, should always be considered as a forced and undesirable measure. Therefore, the criterion of minimum infringement of the interests of employees should be one of the main in making management decisions.

Success in choosing future solutions is facilitated by the application of a systematic approach, according to which a comprehensive, thorough assessment of the whole set of factors influencing the state of the analyzed problem, as well as the effectiveness of the proposed options and the consequences of their implementation.

In solving some problems, the choice of alternatives can be made using formalized procedures, called operations research methods, namely: methods of mathematical programming, queuing theory, mathematical game theory, and others. The choice of these methods - by the person or group who make decisions.

Speaking about the technology of making and implementing management decisions, it is necessary to keep in mind a number of other considerations of technological properties. It is a question of selection of developers of the future decision, about its actual authorship. It is known that the preparation of the necessary decisions (strategic, conceptual, intersectoral, etc.) requires the involvement of qualified professionals "from outside", payment for their business trips and work, the use of technical means, conducting appropriate examinations, conclusions and more.

Thus, in the creative process of making and making decisions, as a rule, a significant number of people are involved, such as the head, his subordinates, consultants, heads of related departments, and so on. Modern computer technology is used, which greatly facilitates the decision-making process. decisions.

The following methods should be used when developing and making management 
Traditional methods should be used only when decisions are made either on the basis of personal experience and intuition of the head, or on the results of special calculations, including economic. These methods must be used to solve problems in terms of certainty, ie in typical standard situations. They are quite common in management practice.

The advantages of traditional methods can be considered their simplicity and long-term use. Also, traditional methods are characterized by shortcomings, which are more pronounced as the problems in the workplace.

Economic and mathematical methods are based on the combined use of mathematical and economic methods in solving practical problems. These include economic and statistical methods, methods of economic cybernetics, optimization methods and econometrics.

The scope of these quantitative methods for solving management problems is limited. Economic and mathematical methods have found application in automated control systems of production processes. The restraining reason in expanding the scope of economic and mathematical methods is that management takes into account various factors, namely: social, organizational and psychological factors, which in most cases can not be expressed in quantitative terms.

The group of systematized methods includes: heuristic methods based on experience and logic, with which an experienced and capable leader chooses the right solution; or the Delphi method, based on the gradual improvement of expert assessments while consistently clarifying a task or problem.

Systematized methods are effective in solving and solving problems in conditions of risk and uncertainty. Here, the main modeling tool is human intelligence, and statistical methods are widely used to process expert estimates.

System-targeted methods can be used in solving related strategic problems. These include methods of systems analysis and program-target methods.

The main methods of systematic analysis of management problems are:

- system decomposition - the method of dividing the system into parts, elements and subsystems to identify the relationships between them and their impact on achieving the goal;

- system diagnostics - a method of studying each of the elements and the system as a whole to identify the most sensory points or "bottlenecks".

Program-target methods are based on the dominant role of the goal, offer means to achieve it. After defining the global goal, a program is developed to achieve it in the form of a "goal tree" and measures are determined to achieve lower-order goals [Error! Reference source not found., with. 330-331].

Thus, the technology of managerial decision-making, of course, needs to use different methods. However, the quantity and quality of management decisions depends on the style of the leader, the situation, the culture of the organization and other factors. Summarizing the various components, management decisions are a way of constant influence of the control subsystem on the managed, which leads to the achievement of goals.

Conclusions.Thus, the study of approaches and methods of development and implementation of management decisions allowed us to determine that the development and adoption of management decisions is a certain sequence of actions (operations), which ensures decision-making. Development and decision-making - a number of different, but fairly typical procedures, which are separate stages in the management process, which allows you to build a general scheme of the management decision-making process. There are two main approaches to making management decisions: centralized and decentralized.Traditional, economicmathematical, systematized and system-target methods should be used in the development and adoption of management decisions.

\section{References:}

1.Lepa, NN (2003) Management of competitive advantages of enterprise: monograph. [Enterprise competitive advantage management: monograph]. Donetsk: OOO YUgo-Vostok, LTD». (in Russian)

2.SHegda AV (2002) Menedzhment: navchal'nij posibnik. [Management: a textbook]. KiC — v: «Znannya». [in Ukrainian]

Дата подання публікації 10.07.2021p. 